\title{
Pengaruh Antara Hypnobirthing, Yoga dan Senam Hamil Terhadap Tingkat Kecemasan Ibu Hamil Trimester III Di BPM Griya Bunda Ceria Palembang Tahun 2020
}

\author{
Zelpina Herlinda Yanti*, Satra Yunola, Putu Lusita Nati Indriani \\ Fakultas Kebidanan dan Keperawatan Universitas Kader Bangsa \\ Jl. Mayjend H.M. Ryacudu No. 8 Ulu Palembang-30452 \\ Telp./Faks: (0711) 510173, 517744 / (0711) 519827, 517744, \\ *Correspondence email: herlindayantizelpina@gmail.com; satrayunola@ymail.com; putu.indriani91@gmail.com
}

\begin{abstract}
Abstrak. Trimester III adalah masa kehamilan yang dihitung dari umur kehamilan minggu ke 28 sampai dengan minggu ke 40 . Perubahan psikis pada ibu hamil diperkirakan terjadi $80 \%$, timbul sifat rasa kecewa, penolakan, kecemasan dan rasa sedih, hal ini akan menjadi lebih kompleks pada kehamilan memasuki trimester ketiga, Tujuan penelitian ini adalah menguji Pengaruh Antara Hypnobirthing, Yoga dan Senam Hamil Terhadap Tingkat Kecemasan Ibu Hamil Trimester III di BPM Griya Bunda Ceria Tahun 2020. Metode penelitian : jenis penelitian kuantitatif, menggunakan metode uji saviro wilk dengan pendekatan pre-test dan posttest Populasi dalam penelitian ini adalah seluruh ibu hamil trimester III yang memeriksakan kehamilannya di BPM Griya Bunda Ceria Palembang. Pengambilan sampel menggunakan teknik purposive sampling. Pengumpulan data dilakukan dengan cara observasi menggunakan lembar kuesioner. Hasil penelitian : didapatkan dari total reponden 15 orang, Berdasarkan hasil uji Saviro Wilt didapat P-value sebesar 0,05 dimana $>\alpha=0,05$ artinya ada pengaruh yang signifikan antara sebelum dan sesudah dilakukan hypnobirthingDengan demikian hipotesa yang menyatakan ada pengaruh hypnobirthing terhadap tingkat kecemasan ibu hamil trimester III yang terbukti secara statistik., didapat p-Value sebesar 0,000 artinya ada pengaruh yang signifikan antara sebelum dan sesudah dilakukan yoga. Dengan demikian hipotesa yang menyatakan ada pengaruh yoga terhadap tingkat kecemasan ibu hamil trimester III yang terbukti secara statistik berdasarkan uji shapiro wilt berpasangan diperoleh p-Value 0,00 pada yoga, p-Value 0,00 pada senam hamil, dan pada hasil uji statistik dikatakan berhubungan apabila nilai p-Value hasil pehitungan $\leq \alpha=0,05$ maka $\mathrm{H}_{\mathrm{o}}$ ditolak artinya signifikan, sehingga kesimpulannya kedua variabel tersebut ada hubungan, sebaliknya apabila $\mathrm{P}$ value hasil perhitungan $>\alpha=0,05$, maka $\mathrm{H}_{\mathrm{o}}$ diterima artinya kedua variabel tersebut tidak ada hubungan secara signifikan.
\end{abstract}

Kata kunci: hypnobirthing; yoga; senam hamil; kecemasan trimester III

Abstract. Trimester III is the period of pregnancy which is calculated from the gestational age of the 28th week to the 40th week. Psychological changes in pregnant women are estimated to occur $80 \%$. third trimester. The purpose of this study was to examine the effect of hypnobirthing, yoga and pregnancy exercise on the anxiety level of third trimester pregnant women at BPM Griya Bunda Ceria in 2020. Research method: quantitative research, using the shapiro wilt test method with pre-test and post-test approaches. in this study were all third trimester pregnant women who checked their pregnancy at BPM Griya Bunda Ceria Palembang. Sampling using purposive sampling technique. Data collection was carried out by means of observation using a questionnaire sheet. The results: obtained from a total of 15 respondents. Based on the results of the Shapiro Wilt test, the p-Value is 0.05 where $>\alpha=0.05$ means that there is a significant influence between before and after hypnobirthing is done.statistically, the p-Value is 0,000, meaning that there is a significant effect between before and after yoga. Thus the hypothesis which states that there is an effect of yoga on the anxiety level of pregnant women in the third trimester which is statistically proven based on the paired shapiro wilt test, the p-Value is 0.00 in yoga, $p$-Value is 0.00 in pregnancy exercise, and the statistical test results are said to be related if the value The calculated $p$-Value $<=0.05$ then Ho is rejected, meaning that it is significant, so the conclusion is that the two variables have a relationship, on the contrary, if the calculated p-Value $>=0.05$, then Ho is accepted, meaning that the two variables have no significant relationship.

Keywords: hypnobirthing; yoga; pregnancy exercise; third trimester anxiety

\section{PENDAHULUAN}

Kecemasan adalah suatu keadaan perasaan afektif yang tidak menyenangkan yang disertai sensasi fisik yang memperingatkan orang terhadap bahaya yang akan datang kepada dirinya (Donsu, 2017).

Untuk mengurangi tingkat kecemasan dan ketakutan ibu hamil trimester III, dalam pemeriksaan trimester III sangat perlu dijelaskan perubahan yang akan terjadi pada dirinya, bidan berperan aktif dalam menjelaskan perubahan terutama perubahan psikologi yang akan dihadapinya. Ibu hamil mulai memikirkan bahwa janin merupakan bagian dari dirinya yang secara keseluruhan bergantung pada dirinya (Triyani, 2013).

Menurut data dari WHO (World health organization) tahun 2017 AKI (angka kematian ibu) sangat tinggi sekitar 295.000 wanita meninggal selama dan setelah kehamilanya. Antara tahun 2000 dan 2017 rasio kematian ibu (AKI) turun sekitar sekitar 38\% diseluruh dunia. Tinggi jumlah kematian ibu di beberapa 
daerah di dunia mencerminkan ketidaksetaraan dalam akses layanan kesehatan (WHO, 2017).

Dari data Kesehatan Masyarakat Universitas Indonesia (KMUI, 2018), berdasarkan data tahun 20182019 angka kematian IBU (AKI) di Indonesia masih tinggi yakni 305 per 1.000 kelahiran hidup. Angka yang muncul hampir $30 \%$ itu masih dianggap tinggi jika dibandingkan Malaysia, yakni 17 per 1.000 kelahiran hidup pada tahun yang sama (KMUI, 2018).

Jumlah kematian ibu maternal di Provinsi Sumatera Selatan sampai dengan bulan desember 2017 mencapai 107 kasus. Dengan jumlah kematian tertinggi yaitu 18 kasus di kab.banyuasin dan jumlah terendah sebanyak 1 kasus masing-masing di kota pagar alam dan kab. OKU Selatan. Namun, masih perlu perhatian kita karena target AKI (angka kematian ibu) berikutnya adalah 304/100.000 KH (Dinkes Palembang, 2017).

Hypnobirthing dapat digunakan untuk menghadapi dan menjalani kehamilan serta persiapan melahirkan dengan cara alami, tenang dan nyaman serta kesehatan jiwa janin

Prenatal yoga selama kehamilan, secara signifikan mampu memperbaiki lower pain, perasaan tidak nyaman dan stress, serta dapat meningkatkan kualitas hidup (Babbar S, Parks-Savage AC, Chaucan SP, 2012).

Menurut penelitian, yoga dapat menurunkan intensitas kecemasan pada ibu hamil trimester III baik itu pada primi dan multipara. Penelitian sebelumnya, yaitu Battledi Amerika Serikat, Bershadsky di California Selatan dan Kinser Virginia menemukan bahwa intervensi prenatal yoga efektif dalam mengurangi kecemasan pada ibu hamil, dengan efektifitas mulai dari $25 \%$ pada relaksasi pertama dan terus meningkat hingga $85 \%$ (Wijayanti, 2014).

Senam hamil akan menghasilkan outcome persalinan yang lebih baik dibandingkan pada ibu hamil yang tidak melakukan senam hamil. Senam hamil dapat menurunkan kecemasan, hal ini sesuai dengan penelitian yang dilakukan oleh Suryani, et al (2015) bahwa dengan dilakukan senam hamil secara teratur yaitu $>8$ kali dalam 6 minggu berpengaruh terhadap penurunan kecemasan pada ibu hamil ( nilai $p=0,026$ ) selain itu juga senam hamil dapat menurunkan kejadian asfiksia pada bayi, menurunkan partus lama dan juga mencegah robekan perineum lebih dari derajat 3 (Suryani, et al, 2015).

Berdasarkan hasil temuan Aliyah (2016), bahwa melakukan senam hamil dapat menurunkan tingkat kecemasan pada ibu hamil dimana senam hamil itu sendiri merupakan salah satu kompetensi dari fisioterapi, pada penelitian ini didapat keefisienan senam hamil yaitu $86,4 \%$ tergantung dengan tingkat keikutsertaan ibu hamil pada kelas ibu tersebut.

Perbedaan yoga dan senam hamil terdapat pada tahapan dan beberapa gerakannya, yaitu pada yoga terdapat tahapan pemusatan pikiran, surya namaskar dan relaksasi akhir dengan posisi tidur berbaring, sedangkan pada senam tidak terdapat hal tersebut.

Berdasarkan data yang diperoleh di BPM Griya Bunda Ceria, didapatkan hasil bahwa yang melakukan ANC selama kurun waktu 2017-2018 adalah sebanyak 135 orang dan yang mengikuti hypnobirthing, yoga dan senam hamil secara intensif sebanyak 76 orang ( $56.3 \%$ ). Sedangkan dari seluruh ibu hamil baik yang melakukan kunjungan pemeriksaan kehamilan dan yang mengikuti hypnobirthing, yoga dan senam hamil, terdapat $105 \mathrm{ibu}$ yang melahirkan secara normal. Data tahun 2018-2019 yang melakukan ANC sebanyak 150 orang dan yang mengikuti hypnobirthing, yoga dan senam hamil secara intensif sebanyak 115 orang ( $70 \%$ ).

Studi pendahuluan yang dilakukan Bingan (2019) yang mengatakan bahwa pengaruh yang signifikan dengan nilai $p$-value $0,000(\alpha=0,05)$ yang membuktikan bahwa ada Pengaruh antara variabel independen (Prenatal Gentle Yoga) dengan variabel dependen (tingkat kecemasan) dalam menurunkan tingkat kecemasan pada ibu hamil trimester III. Ada Pengaruh antara prenatal gentle yoga dalam menurunkan tingkat kecemasan pada ibu hamil trimester III di PMB wilayah kerja Kereng Bangkirai Kota Palangka Raya.

yang mengatakan kecemasan ibu hamil sebelum dilakukan senam hamil diukur dengan kuesioner HARS, hasilnya 33\% mengalami kecemasan ringan, $44 \%$ mengalami kecemasan sedang, dan $22 \%$ mengalami kecemasan berat. Setelah dilakukan senam hamil, kecemasan ibu hamil mengalami penurunan yaitu $44 \%$ tidak mengalami kecemasan, $22 \%$ mengalami kecemasan ringan, dan 22\% mengalami kecemasan sedang.(Maulida Dan Wahyuni 2020 )

senam hamil bermanfaat bagi ibu hamil agar ibu menguasai tekhnik pernafasan. Tekhnik pernafasan ini dilatih agar ibu lebih siap menhadapi persalinan. Dengan tekhnik pernafasan yang baik, maka pola nafas pada ibu hamil pun menjadi lebih baik dan teratur sehingga dapat memberikan perasaan rileks pada ibu hamil. Relaksasi akan menghambat peningkatan kerja saraf otonom simpatetik, sehingga sistem saraf parasimpatetik yang memiliki fungsi kerja berlawanan dengan saraf simpatetik. Hal ini kemudian dapat menurunkan hormon adrenalin sehingga terjadi penurunan detak jantung, irama nafas, tekanan darah, ketegangan otot, tingkat metabolisme dan produksi hormon penyebab stress yang menyebabkan ibu hamil menjadi lebih tenang seiring dengan menurunnya gejala kecemasan Sulastri (2017),

\section{METODE}

Jenis penelitian yang digunakan dalam penelitian ini bersifat quasy experimental (eksperimen semu) artinya eksperimen ini belum atau tidak memiliki ciriciri rancangan eksperimen yang sebenarnya, karena variabel yang seharusnya dikontrol atau dimanipulasi tidak dapat atau sulit dilakukan (Notoatmodjo,2011), dengan pendekatan pretest dan posttest with control 
Zelpina Herlinda Yanti, Satra Yunola dan Putu Lusita Nati Indriani, Pengaruh Antara Hypnobirthing, Yoga dan Senam Hamil Terhadap Tingkat Kecemasan Ibu Hamil Trimester III Di BPM Griya Bunda Ceria Palembang Tahun 2020

groub design, dimana data ini menyangkut variabel independen (hypnobirthing, yoga dan senam hamil ) dan variabel dependen ( tingkat kecemasan ibu hamil trimester III.Penelitian ini dilakukan pada bulan Juli s/d Agustus 2020. Populasi penelitian ini adalah seluruh ibu hamil TM III sebnyak 30 responden dibagi menjadi dua kelompok, kelompok yang diberikan perlakuan 15 responden dan kelompok kontrol 15 responden. penelitian ini diperoleh secara langsung dengan wawancara yang dipandu oleh kuesioner. Analisis data dalam penelitian ini adalah analisis univariat dan bivariat.

\section{HASIL DAN PEMBAHASAN Analisis Univariat}

Tabel 1. Uji Normalitas

\begin{tabular}{lcc}
\hline Variabel & n & p-Value \\
\hline Hypnobirthing & 15 & \\
$\quad$ Pretest & & 0,002 \\
Posttest & & 0,005 \\
Yoga & 15 & \\
$\quad$ Pretest & & 0,070 \\
Posttest & & 0,000 \\
Senam Hamil & 15 & \\
$\quad$ Pretest & & 0,034 \\
Posttest & & 0,012 \\
\hline
\end{tabular}

Menunjukan bahwa dari 15 sampel penelitian Uji normalitas data dilakukan dengan menggunakan Shapiro Wilk karena jumlah sampel penelitian kurang dari 50 sampel. Hasil yang didapat pada tingkat kecemasan sebelum pemberian hypnobirthing dengan 15 responden didapat p-Value 0,002 dan setelah dilakukan hypnobirthing didapat p-Value 0,005 berarti nilai $\mathrm{p}<0,005$ maka didapat kesimpulan bahwa data berdistribusi normal. Pada derajat tingkat kecemasan sebelum dilakukan yoga didapatkan nilai p-Value 0,070 dan setelah dilakukan yoga didapatkan nilai p-Value 0,000 berarti nilai $\mathrm{p}$ value $<0,05$ maka didapatkan kesimpulan bahwa data berdistribusi normal. Pada derajat tingkat kecemasan sebelum dilakukan senam hamil didapatkan nilai p-Value 0,034 dan setelah dilakukan senam hamil didapatkan nilai p-Value 0,012 berarti nilai p-Value $<0,05$ maka didapatkan kesimpulan bahwa data berdistribusi normal.

Tabel 2. Distribusi Frekuensi Tingkat Kecemasan Sebelum Hypnobirthing Ibu Hamil Trimester III di BPM Griya Bunda Ceria Palembang Tahun 2020

\begin{tabular}{|lcc}
\hline Hypnobitthing & f & \% \\
\hline 0-10 (Tidak cemas) & 1 & 6,7 \\
11-20 (Ringan) & 4 & 26,7 \\
21-27 (Sedang) & 2 & 13,3 \\
31-90 (Berat) & 8 & 53,3 \\
\hline Total & $\mathbf{1 5}$ & $\mathbf{1 0 0}$ \\
\hline
\end{tabular}

Tabel 2 menunjukkan dari 15 responden (100\%) tingkat kecemasan sebelum hypnobirthing pada kecemasan berat sebanyak 8 responden $(53,3 \%)$ dan paling sedikit 1 responden $(6,7 \%)$.

Tabel 3. Distribusi Frekuensi Tingkat Kecemasan Setelah Hypnobirthing Ibu Hamil Trimester III di BPM Griya Bunda Ceria Palembang Tahun 2020

\begin{tabular}{|lcc|}
\hline Hypnobirthing & f & $\%$ \\
\hline $0-10$ ( Tidak Cemas) & 2 & 13,3 \\
11-20 ( Ringan) & 3 & 20,0 \\
21-30 ( Sedang) & 3 & 20,0 \\
$31-90$ (Berat) & 7 & 46,7 \\
\hline Total & $\mathbf{1 5}$ & $\mathbf{1 0 0}$ \\
\hline
\end{tabular}

Tabel 3 menunjukkan tingkat kecemasan setelah hypnobirthing pada kecemasan berat sebanyak 7 responden $(46,7 \%)$ dan yang tidak mengalami cemas 2 responden $(13,3 \%)$.

Tabel 4. Distribusi frekuensi tingkat kecemasan sebelum Yoga Ibu Hamil Trimester III di BPM Griya Bunda Ceria Palembang Tahun 2020

\begin{tabular}{|lcc|}
\hline Hypnobirthing & f & $\%$ \\
\hline <14 (Tidak Cemas) & 3 & 20,0 \\
$14-20$ (Ringan) & 6 & 40,0 \\
$21-27$ (Sedang) & 4 & 26,7 \\
28-41 (Berat) & 2 & 13,3 \\
\hline Total & $\mathbf{1 5}$ & $\mathbf{1 0 0}$ \\
\hline
\end{tabular}

Tabel 4 menunjukkan tingkat kecemasan sebelum yoga kecemasan berat sebanyak 2 responden $(13,3 \%)$ dan yang tidak mengalami cemas sebanyak 3 responden $(20,0 \%)$.

Tabel 5. Distribusi frekuensi tingkat kecemasan setelah yoga Ibu Hamil Trimester III di BPM Griya Bunda Ceria Palembang Tahun 2020

\begin{tabular}{|lcr|}
\hline Yoga & f & $\%$ \\
\hline$<14$ (Tidak Cemas) & 9 & 60,0 \\
$14-20$ (Ringan) & 5 & 33,0 \\
$21-27$ (Sedang) & 1 & 6,7 \\
\hline Total & $\mathbf{1 5}$ & $\mathbf{1 0 0}$ \\
\hline
\end{tabular}

Tabel 5 menunjukkan tingkat kecemasan setelah yoga tidak ada lagi kecemasan berat. Pada kecemasan sedang sebanyak 1 responden $(6,7 \%)$ dan yang tidak mengalami kecemasan sebanyak 9 responden $(60,0 \%)$. persentase saat sesi postest yaitu sebanyak 6 orang (40.0\%) tidak mengalami kecemasan dan 1 orang $(6.7 \%)$ mengalami kecemasan berat. 
Zelpina Herlinda Yanti, Satra Yunola dan Putu Lusita Nati Indriani, Pengaruh Antara Hypnobirthing, Yoga dan Senam Hamil Terhadap Tingkat Kecemasan Ibu Hamil Trimester III Di BPM Griya Bunda Ceria Palembang Tahun 2020

Tabel 6. Distribusi frekuensi tingkat kecemasan sebelum Senam Hamil Ibu Hamil Trimester III di BPM Griya Bunda Ceria Palembang Tahun 2020

\begin{tabular}{|lcr|}
\hline Senam Hamil & f & $\%$ \\
\hline$<14$ (Tidak Cemas) & 1 & 6,7 \\
$14-20$ (Ringan) & 3 & 20,0 \\
$21-27$ (Sedang) & 4 & 26,7 \\
$28-41$ (Berat) & 4 & 26,7 \\
$42-56$ (Sangat Berat) & 3 & 13,3 \\
\hline Total & $\mathbf{1 5}$ & $\mathbf{1 0 0}$ \\
\hline
\end{tabular}

Tabel 6 menunjukkan tingkat kecemasan sebelum senam hamil kecemasan sangat berat sebanyak 3 responden $(13,3 \%)$ dan yang tidak mengalami cemas 1 responden $(6,7 \%)$.

Tabel 7. Distribusi frekuensi tingkat kecemasan setelah Senam Hamil Ibu Hamil Trimester III di BPM Griya Bunda Ceria Palembang Tahun 2020

\begin{tabular}{|lcr|}
\hline Senam Hamil & f & $\%$ \\
\hline$<14$ (Tidals cemas) & 2 & 13,3 \\
$14-20$ (Ringan) & 4 & 26,7 \\
$21-27$ (Sedang) & 4 & 26,7 \\
$28-41$ (Berat) & 3 & 20,0 \\
$42-56$ (Sangat Berat) & 2 & 13,3 \\
\hline Total & $\mathbf{1 5}$ & $\mathbf{1 0 0}$ \\
\hline
\end{tabular}

Tabel 7 menunjukkan tingkat kecemasan setelah senam hamil pada kecemasan berat sebanyak 2 responden $(13,3 \%)$ dan yang tidak mengalami kecemasan sebanyak 2 responden $(13,3 \%)$.

\section{Analisa Bivariat}

Nilai rata-rata pengaruh hypnobirthing terhadap tingkat kecemasan sebelum dan setelah hypnobirthing serta hasil uji statistik menggunakan t-test dapat dilihat pada tabel 8 .

Tabel 8. Pengaruh Antara Hypnobirthing Terhadap Tingkat Kecemasan Ibu Hamil Trimester III Di BPM Griya Bunda Ceria Palembang Tahun 2020

\begin{tabular}{|l|c|c|c|}
\hline \multicolumn{1}{c|}{ Subjek penelitian } & f & $\begin{array}{c}\text { Tingkat kecemasan } \\
\text { Mean } \pm \text { SD }\end{array}$ & p-Value \\
\hline $\begin{array}{l}\text { Kelompok sebelutm } \\
\text { hypnobirthing } \\
\begin{array}{l}\text { Kelompoks setelah } \\
\text { hypnobirthing }\end{array}\end{array}$ & 15 & $33.53=13.501$ & 0,000 \\
\hline
\end{tabular}

Pada tabel 8 menunjukkan rata-rata tingkat kecemasan sebelum hypnobirthing didapat nilai mean 33.53 dengan standar deviasinya 13.501 yang diukur dengan skala distress, setelah dilakukan hypnobirthing didapat nilai mean 28.87 dengan standar deviasinya 12.124, maka disini bisa dilihat bahwa ada penurunan nilai meannya. Dari hasil uji statistik didapatkan nilai pValue 0,000 maka dapat disimpulkan bahwa terdapat pengaruh yang signifikan antara sebelum hypnobirthing dan sesudah hypnobirthing terhadap penurunan tingkat kecemasan ibu hamil trimester III.

Nilai rata-rata pengaruh yoga terhadap tingkat kecemasan sebelum dan setelah yoga serta hasil uji statistik menggunakan $t$-test dapat di lihat pada tabel 5.9

Tabel 9. Pengaruh Antara Yoga Terhadap Tingkat Kecemasan Ibu Hamil Trimester III Di BPM Griya Bunda Ceria Palembang Tahun 2020

\begin{tabular}{|l|c|c|c|}
\hline Subjek penelitian & f & $\begin{array}{c}\text { Tingkat } \\
\text { kecemasan } \\
\text { Mean } \pm \text { SD }\end{array}$ & p-Value \\
\hline $\begin{array}{l}\text { Kelompok sebelum } \\
\begin{array}{l}\text { yoga } \\
\text { Kelompok setelah } \\
\text { yoga }\end{array}\end{array}$ & 15 & $19.67 \pm 56.27$ & 0,000 \\
\hline
\end{tabular}

Berdasarkan tabel 9 rata-rata tingkat kecemasan sebelum dilakukan yoga didapat nilai mean 19.67 dengan standar deviasinya 56.27, dibandingkan dengan setelah dilakukan yoga didapat mean 13.20 dengan standar deviasinya 4.395, maka dapat dilihat bahwa ada pengurangan nilai yang diukur dengan skala kecemasan. Hasil uji statistik didapatkan nilai p-Value 0,000 maka dapat disimpulkan bahwa terdapat pengaruh yang signifikan antara sebelum yoga dan sesudah dilakukannya yoga.

Nilai rata-rata pengaruh senam hamil terhadap tingkat kecemasan sebelum dan setelah senam hamil serta hasil uji statistik menggunakan t-test dapat dilihat pada tabel 10 .

Tabel 10. Pengaruh Antara Senam Hamil Terhadap Tingkat Kecemasan Ibu Hamil Trimester III Di BPM Griya Bunda Ceria Palembang Tahun 2020

\begin{tabular}{|l|c|c|c|}
\hline \multicolumn{1}{|c|}{ Subjek penelitian } & f & $\begin{array}{c}\text { Tingkat kecemasan } \\
\text { Mean } \pm \text { SD }\end{array}$ & p-Value \\
\hline $\begin{array}{l}\text { Kelompok sebelum } \\
\text { Senam Hamil } \\
\begin{array}{l}\text { Kelompok setelah } \\
\text { Senam Hamil }\end{array}\end{array}$ & 15 & $21.20 \pm 6.868$ & 0,000 \\
\hline
\end{tabular}

Berdasarkan tabel 10 rata-rata tingkat kecemasan sebelum senam hamil didapatkan nilai mean 21.20 dengan standar deviasinya 6.868 dibandingkan dengan setelah dilakukan senam hamil didapat nilai mean 17.73 dengan standar deviasinya 7.136 yang diukur dengan skala kecemasan. Hasil uji statistik didapatkan nilai pValue 0,000 maka dapat disimpulkan bahwa terdapat pengaruh yang signifikan antara sebelum senam hamil dan sesudah dilakukan senam hamil.

Berdasarkan uji- $t$ berpasangan seperti yang ditunjukkan pada tabel 5.6 diperoleh $p$ value pada kelompok perlakuan yaitu $0,00 \quad(<0,05)$ pada Hypnobirting, $p$ value 0,00 pada yoga, $p$ value 0,00 pada senam hamil dan pada kelompok kontrol 0,312 (>0,05), yang berarti menunjukkan terjadi pebedaan antara kelompok yang mendapat perlakuan dengan yang tidak 
mendapat perlakuan. Hal ini menunjukkan bahwa (Hypnobirting, Yoga dan Senam hamil) dapat mengurangi kecamasan pada ibu Trimester III.

\section{Pembahasan}

Berdasarkan hasil penelitian yang dilakukan di BPM Griya Bunda Ceria Palembang, pada tabel 5.2 di atas didapat bahwa dari 15 responden ibu hamil trimester III sebelum dilakukan hypnobirthing sebanyak 8 responden $(53,3 \%)$ dan pada tabel 5.3 di atas didapat sesudah dilakukan hypnobirthing sebanyak 7 responden $(46,7 \%)$.

Berdasarkan hasil uji Saviro Wilt 0,808 pada tabel 5.8 didapat p-Value sebesar 0,05 dimana $<\alpha=0,05$ artinya ada pengaruh yang signifikan antara sebelum dan sesudah dilakukan hypnobirthing. Dengan demikian hipotesa yang menyatakan ada pengaruh hypnobirthing terhadap tingkat kecemasan ibu hamil trimester III yang terbukti secara statistik.

Hasil penelitian ini juga sejalan dengan penelitian Enggar, et all (2014) tentang efektivitas hypnobirthing, dimana didapat analisis nilai p-value sebesar $0,000<$ 0,05 , harga $\mathrm{t}$ hitung lebih besar dari t tabel $(22,905>$ 1,740), maka dapat disimpulkan hypnobirthing mempunyai efektivitas yang signifikan terhadap lamanya proses persalinan. Ibu yang mengikuti kelas hypnobirthing mempunyai emosional yang lebih positif dan tidak mengalami masalah psikologis.

Berdasarkan hasil penelitian yang dilakukan di BPM Griya Bunda Ceria Palembang, pada tabel 5.4 di atas didapat bahwa dari 15 responden ibu hamil trimester III sebelum dilakukan yoga sebanyak 2 responden $(13,3 \%)$ dan pada tabel 5.5 di atas didapat sesudah dilakukan yoga tidak ada lagi kecemasan berat, hanya pada kecemasan sedang 1 responden $(6,7 \%)$.

Berdasarkan hasil uji Saviro Wilt 0,713 pada tabel 5.9 didapat p-Value sebesar 0,000 artinya ada pengaruh yang signifikan antara sebelum dan sesudah dilakukan yoga. Dengan demikian hipotesa yang menyatakan ada pengaruh yoga terhadap tingkat kecemasan ibu hamil trimester III yang terbukti secara statistik.

Sedangkan hasil yang telah dilakukan oleh Pujianti (2018) responden yang tidak rutin melakukan senam hamil didapatkan persalinan cepat yaitu 11 responden $(73,3 \%)$ dimana responden yang tidak rutin melakukan yoga memiliki lama persalinan, karena waktu yang dibutuhkan saat persalinan kaln 1 fase aktif pada primigravida kurang dari 6 jam dan kurang dari 3 jam pada multipara.

Hal ini juga sejalan dengan penelitian bingan (2019) yang mengatakan bahwa pengaruh yang sangat signifikan dengan nilai p-Value $0,000(\alpha<0,05)$ yang membuktikan bahwa ada pengaruh antara variabel independen (yoga) dengan variabel dependen (tingkat kecemasan) yang dilakukan penelitian di BPM wilayah kerja Kereng Bingkirai Kota Palangka Raya.
Berdasarkan hasil penelitian yang dilakukan di BPM Griya Bunda Ceria Palembang, pada tabel 5.6 di atas didapat bahwa dari 15 responden ibu hamil trimester III sebelum dilakukan senam hamil sebanyak 3 responden $(13,3 \%)$ dan pada tabel $5.7 \mathrm{di}$ atas didapat sesudah dilakukan senam hamil sebanyak 2 responden $(13,3 \%)$.

Berdasarkan hasil uji Saviro Wilt didapat pada tabel 5.10 didapat p-Value 0,012 dimana $>\alpha=0,05$ artinya ada pengaruh yang sangat signifikan antara sebelum dan sesudah dilakukan senam hamil. Dengan demikian hipotesa yang menyatakan ada pengaruh senam hamil terhadap tingkat kecemasan ibu hamil trimester III yang terbukti secara statistik.

Melakukan senam hamil dapat menurunkan tingkat kecemasan pada ibu hamil, dimana senam hamil ini sendiri merupakan suatu kompetensi dari fisioterapi. Selain gerakan relaksasi, ada pula gerakan untuk pengaturan pernapasan yang selain membantu ibu saat melahirkan, juga dapat memberikan rasa tenang dan rileks pada ibu hamil, akibatnya terjadi penurunan detak jantung, irama nafas, tekanan darah, ketegangan otot dan penurunan hormon penyebab stres (Esthini, 2016).

\section{SIMPULAN}

Berdasarkan hasil penelitian tentang "Pengaruh Antara Hypnobirthing, Yoga dan Senam Hamil Terhadap Tingkat Kecemasan Ibu Hamil Trimester III di BPM Griya Bunda Ceria Palembang Tahun 2020", dapat disimpulkan diperoleh Berdasarkan hasil uji Saviro Wilt didapat P-value sebesar 0,05 dimana $>\alpha=0,05$ artinya ada pengaruh yang signifikan antara sebelum dan sesudah dilakukan hypnobirthingDengan demikian hipotesa yang menyatakan ada pengaruh hypnobirthing terhadap tingkat kecemasan ibu hamil trimester III yang terbukti secara statistik., didapat p-Value sebesar 0,000 artinya ada pengaruh yang signifikan antara sebelum dan sesudah dilakukan yoga. Dengan demikian hipotesa yang menyatakan ada pengaruh yoga terhadap tingkat kecemasan ibu hamil trimester III yang terbukti secara statistik berdasarkan uji shapiro wilt berpasangan diperoleh p-Value 0,00 pada yoga, p-Value 0,00 pada senam hamil, dan pada hasil uji statistik dikatakan berhubungan apabila nilai $\mathrm{p}$-Value hasil pehitungan $\leq \alpha=$ 0,05 maka $H_{o}$ ditolak artinya signifikan, sehingga kesimpulannya kedua variabel tersebut ada hubungan, sebaliknya apabila $\mathrm{P}$ value hasil perhitungan $>\alpha=0,05$, maka $\mathrm{H}_{\mathrm{o}}$ diterima artinya kedua variabel tersebut tidak ada hubungan secara signifikan.

\section{DAFTAR PUSTAKA}

Aliyah, jannatin. 2016. Pengaruh Pemberian Senam Hamil Terhadap Tingkat Kecemasan Dan Kualitas Tidur Ibu hamil Di Puskesmas Samata. Gowa:Jurnal 77626857.pdf 
Zelpina Herlinda Yanti, Satra Yunola dan Putu Lusita Nati Indriani, Pengaruh Antara Hypnobirthing, Yoga dan Senam Hamil Terhadap Tingkat Kecemasan Ibu Hamil Trimester III Di BPM Griya Bunda Ceria Palembang Tahun 2020

Babbar S, Parks-Savage AC, Chauhan SP. Yoga during pregnancy: a review. American Journal of Perinatology. 2012; 29(6):459-64.

Dinkes Palembang (2017). Profil Kesehatan Tahun 2017 , https://dinkes.palembang.go.id/tampung/dokumen /dokumen-157-281.pdf

Donsu, Jenita Doli Tine. Psikologi Keperawatan. Yogyakarta: Pustaka Baru Press, 2017.

KMUI, 2018 Pengaruh Kelas Ibu Hamil Terhadap Kecemasan Ibu Primigravida Di Puskesmas Wates Kabupaten Kulon Progo. Yogyakarta:Skripsi (Full).pdf

Notoatmodjo S. Kesehatan Masyarakat Ilmu dan Seni. Jakarta: Rineka Cipta; 2011.

Sulastri, 2017 Senam Hamil Meningkatkan Antioksidan Enzimatik, Kekuatan Otot Panggul, Kualitas Jasmani Dan Menurunkan Kerusakan Oksidatif Pada Wanita Hamil. Denpasar:Universitas Uduyana.

Suryani, I; Mose, J.C: Tarawan V.M: Husin. F: Prasetyo.D (2015) Pengaruh Senam Hamil Teratur Pada Primigavida Terhadap Perubahan Psikofisiologis Ibu dan BBL Bayi IJEMC, Volume 3 no.3.

Triyani, 2013 Kecemasan ibu hamil dalam menghadapi proses persalinan. Sumarni, Syaifurrahman Hidayat \& Sri.s.1.: Jurnal Kesehatan Wiraraja Medika

Wijayanti, M.T. 2014. Pengaruh Pendidikan Kesehatan Terhadap Pengetahuan Dan Kecemasan Pada Wanita Pre Menopause di Desa Jendi Kecamatan Selogiri Kabupaten Wonogiri. Tesis. Surakarta: Program Pasca Sarjan Iniversitas Sebelas Maret.

World Health Organization (2017). Mental disorders fact sheets. World Health Organization. http://www.who.int/mediacentre/factsheets/fs396/ en/ 